\title{
An Empirical Basis of Multi-Level Governance Approach: Subnational Mobilisation in the European Union Arena
}

\author{
Ali Onur ÖZÇELIK*
}

An Empirical Basis of Multi-Level Governance Approach: Subnational Mobilisation in the European Union Arena

Abstract

The concept of multi-level governance (MLG) and its empirical implications to subnational mobilisation in the EU arena is a key subject of this article. The primary focus here is on the subnational level of analysis and its integration in and interaction with the EU multi-level polity. The obvious reason for writing this article is that the extent to which the interplay between supranational institutions and SNAs has affected intergovernmental relations and caused subnational mobilisation across the EU arena is an empirical matter. Empirically, the creation of MLG in member (and applicant) states and its impact over subnational mobilisation have been exclusively discussed within the context of EU regional policy and related financial incentives. In this respect, this article seeks to explain how the Europeanization of regional policy relates to theoretical concerns with multi-level governance and to find out the extent to which the process of Europeanization contributes to the creation of multi-level modality in member, and particularly, applicant states.

Key Words: Multi-level governance, subnational mobilization, territorial representation, EU Regional and Structural Policy, member and candidate states

\section{Introduction}

Through the integration process and ongoing regionalization in many parts of Europe, numbers of scholars have focused on developments on the subnational level. Scholarly attention on

* Ali Onur ÖZÇELiK, Arş. Gör., Eskişehir Osmangazi Üniversitesi, İktisadi ve İdari Bilimler Fakültesi, Uluslararası Illişkiler Bölümü, alionur.ozcelik@gmail.com
Çok Boyutlu Yönetişim Yaklaşımının Ampirik Temeli: Avrupa Birliği Arenasında Ulusaltı Hareketlilik

Özet

Çok Boyutlu Yönetişim (Multi-level Governance) kavramı ve bu kavramın Avrupa Birliği arenasında ampirik uyguluması olan ulusaltı hareketlilik bu makalenin ana konusudur. Makalenin odağı ulusaltı düzeyin analizi ve ulusaltının entegrasyonla ve çok boyutlu $A B$ siyasası ile etkileşimidir. Ulusüstü kurumlarla ulusaltı kurumların etkileşiminin hükümetler arası ilişkileri etkilemesi ve $\mathrm{AB}$ arenasında ulusaltı hareketliliğe neden olmasının ampirik bir konuyu teşkil etmesi bu makalenin yazılmasındaki en bariz nedendir. Ampirik olarak, çok boyutlu yönetişimin üye ve aday ülkelerde kurulması ve bunun ulusaltı hareketliliğe etkisi $A B^{\prime}$ nin bölgesel politikaları ve ilgili finansal destekleri bağlamında tartışımışıı. Bu bakımdan, bu makale bölgesel politikaların Avrupalılaşmasının, çok boyutlu yönetişimin teorik unsurları ile nasıl bağdaştı̆̆ını açıklamaya çalışacak ve Avrupalılaşma sürecinin üye ve aday ülkelerde ne ölçüde çok boyutlu bir siyasa yarattığını araştıracaktır.

Key Words: Çok Boyutlu Yönetişim, ulusaltı hareketlilik, mekansal temsiliyet, $A B$ Bölgesel ve Yapısal Politikaları, üye ve aday ülkeler 


\section{Ali Onur ÖZÇELIK}

how to analyse the role SNAs play in European integration has increased dramatically in the literature through the 1990s (Hooghe, 1995; Keating and Jones, 1995; Le Gales and Lequesne, 1998; Jeffrey, 2000). A burgeoning literature has emerged around what has been termed "subnational mobilization" (Hooghe, 1995), "territorial representations" (Moore, 2012) and "the growing engagement of sub-national governmental actors with the institutions and process of EU policymaking" (Jeffrey, 2000). Among other developments in the EU integration process ${ }^{1}$, the Maastricht Treaty of 1992 could be perceived as the turning point for the involvement of SNAs to the EU politics as it was a solid recognition of the multi-layered structure of the EU governance (Hooghe and Marks, 2001).

The integration process along with the enlargement have not only underpinned the power shift towards Brussels, making many SNAs reposition their activity towards the EU level, but also fortified channels (i.e. the Committee of Regions, the EU Parliament, and the EU Council) for SNAs to directly interact with EU institutions and represent their territorial interests to the broader audience in Brussels. As a result, the examination of subnational activities and their engagement with the EU politics has served as a fruitful source of and leverage for theoretical development in European integration studies (Marks, 1993; Hooghe, 1995; Marks et al. 1995). The Multi-Level Governance (MLG) approach may be considered as one of the most sophisticated accounts for explaining the foreign activities of SNAs in Brussels (Blatter et al. 2009). The remainder of this paper, therefore, suggests that the most promising way forward is to link the notion of MLG with the concept of subnational mobilization and '(functional) territorial interest representation' ${ }^{2}$ in the EU.

For a holistic coverage of the theoretical and empirical evolution of subnational mobilisation in a European context, the article is divided into four parts. The first part identifies the changes which have caused subnational mobilisation in the wider context of the role of regions in the EU. It then analyses the extent to which European integration has created opportunity structures for SNAs in the EU arena. The second part examines the outcomes of changing EU regional policy and funding regimes on the behaviour of SNAs in member and candidate states. Next to these main issues, the third part presents the European activities of SNAs and the channels that they use to engage with the EU polity. Mainly focusing on empirical-driven literature on the mobilisation of SNAs in the EU, the article concludes with the implications of subnational mobilisation to the new members (especially CEECs) during their accession rounds.

\footnotetext{
${ }^{1}$ Other relevant developments include: the completion of the internal market; the revise treaties of Single European Act, the Maastricht treaty; the subsequent reforms of structural funds and Cohesion policies; the launch of the principles of partnership, additionality and subsidiarity; the creation of the Committee of Regions (the CoR); right to attend the Ministry of Council meetings for some privileged regions (Article 213).

${ }^{2}$ Functional territorial interest representation here does not refer to any ethnic regionalist movement, rather it refers to participating inter-regional networks, interacting with the EU's formal and informal institutions and/or setting up an office in order for getting fund, liaising, networking, lobbying.
} 
Eskişehir Osmangazi Üniversitesi Sosyal Bilimler Dergisi

\section{A Historical Overview}

\subsection{Changing Opportunity Structures for SNAs in the European Arena}

Subnational mobilisation within a broader political game across Europe has become a centre of attention for several scholars from different disciplines ${ }^{3}$. Research on European regionalism ${ }^{4}$, studies within the Europeanization literature and the multi-level governance perspective generally provide insights into the content and scope of subnational activities and account for understanding the dynamics of changing intergovernmental relations in which SNAs from member (and candidate) states can exercise the functions of subnational mobilisation. Several accounts and concepts, particularly within the new regionalist literature, i.e., paradiplomacy, multi-layered diplomacy and the like, touch upon the concepts of subnational mobilisation and territorial representations outside national settings.

Scholars from the new regionalist tradition have delineated various structural reasons (both exogenous and endogenous) to account for the international activities of SNAs in the EU arena ${ }^{5}$. Three structural reasons, somewhat related to each other, predominantly appear to explain the extent to which SNAs have become the centre of attention in the system of EU governance through the 1980s and 1990s. The rising importance of regions in the globalized economy (so-called glocalization effect) (Keating and Loughlin, 1997; Amin, 1999; Goldsmith and Page, 2010); trends towards decentralization and devolution of competences to regions and localities in many states (Marks, 1997; Bullmann, 1997); and the transformations of EU regional policy over time (Jeffrey, 1997a; 2000) are deemed as central factors bringing about a great deal of new territorial groups in the international arena.

The rise of regions in the globalized economy and trends towards decentralization in many parts of Europe are closely related to the transformation of EU regional policy and governance particularly after the mid-1970s6. Along with the rise of regions in the global economy, or what

\footnotetext{
${ }^{3}$ Scholarly endeavours and their concepts to describe this novel type of territorial politics in the EU vary considerably. As such, the 1990s have been the era of a 'Europe of the regions' (Mazey and Mitchell, 1993; Loughlin 1996), 'a Europe with the regions' (Hooghe, 1995, Marks et al., 1996; Hooghe and Marks, 2001), 'a Europe with certain regions' (Hooghe, 1996; Marks et al., 1996; Le Galès and Lequesne, 1998), 'a Europe through regions' (Kukawka, 2001 cited in Tatham, 2008), the emergence of 'a third level' in European decision making (Jeffrey, 1997a; 2000; Bullmann, 1997) and the evolution of a system of MLG in the EU (Marks, 1993). A burgeoning literature (Hooghe 1995; 1996; Jeffrey, 1997a; 2000; Keating, 1998; Le Galès and Lequesne, 1998) has emerged around what have been termed subnational mobilisation (Hooghe, 1995), paradiplomacy (Keating and Aldecoa, 1999), territorial representations (Moore, 2008a; 2011) and the foreign activities of subnational actors (Blatter et al., 2008; 2009).

${ }^{4}$ Such as Keating and Jones, 1995; Jeffrey, 1997a; 2000; Bullmann, 1997; Bomberg and Peterson, 1998; Le Galès and Lequesne, 1998; Goldsmith and Page, 2010; Fitjar, 2010.

${ }^{5}$ In one of the recent empirical-driven studies, Fitjar (2010) particularly illustrates the main causes behind the regional mobilisation in Western Europe by identifying five broad explanatory factors: globalization, Europeanization, cultural distinctiveness, regionalized party system and economic development.
}

${ }^{6}$ For rich explanation on this account, see Sharpe, 1993 and Amin, 1999 


\section{Ali Onur ÖZÇELIK}

Sharpe $^{7}$ (1993) describes as the rise of meso-level governments, many members particularly from the EU-15 have gone through a process of administrative and political reorganization during the last three decades (Bullmann, 1997:4). Decentralizations and devolution of competences to regions and localities (Keating and Loughlin, 1997) in those states have increased the capacity of the subnational level (Moore, 2008a, p. 519). Even if such developments produced divergent outcomes in line with the specific structures and influences in each nation-state, a number of SNAs embarked on the institutionalization process by gaining more sources and powers at home. Subsequently, they have conducted activities outside their national border.

Although the majority of scholars have referred to the same phenomenon, that is the growing importance of regions in the global economy, two approaches have become dominant. Some scholars, on the one hand, have put more emphasis on exogenous factors, i.e. globalization and Europeanization (Marks et al., 1996; Kohler-Koch and Eising, 1999); other scholars, on the other hand, have placed a greater emphasis on endogenous factors producing more interdependent actors (Sharpe, 1993; Keating and Loughlin, 1997). The aim here is not to take issue with the broad notion of 'state transformation' ${ }^{8}$ because a number of scholars have already done that (Rosenau and Czempiel, 1992; Ohmae, 1996; Sørensen, 2006). It is, however, sufficient to underline that many western industrialized states have increasingly felt under enormous pressure from above and below for the last three decades (Keating and Hooghe, 1996). In appreciating the idea that international and subnational pressure has simultaneously reduced the autonomy of the nationstate, some scholars from the traditions of comparative politics correspondingly describe this as "the hollowing out of the state"9 (Bulmer and Lequesne, 2005, p. 2).

In light of the above discussion, it is crucial to determine how one links the discussion of the transformations of local and regional administrations to the multi-level system of EU governance. In applying the new institutionalist account as a theoretical background, Dobre (2007) examines the contribution of the new regionalist tradition and Europeanization literature to domestic politics with regard to the institutional change at the regional levels in Spain and Romania. What she discusses is that both strands of literature identify the conditions for change at the EU and domestic levels, which are conceptually defined as exogenous and endogenous explanatory variables. There is, nonetheless, a clear difference in their analytical approach to the research object. In this respect, she argues that while the impact of Europeanization on domestic change is only one

\footnotetext{
${ }^{7}$ According to Sharpe (1993), there has been a general trend toward decentralization in most western countries since the 1970s, the most important exception being in the UK, which witnessed an increased centralization under Margaret Thatcher. By contrast, France is a good example to show this decentralization effort, which was undertaken by the Raffarin government in 1982.

${ }^{8}$ Sørensen (2006:190-191) argues that there are three standpoints in the debate on the transformation of state: 'retreat of the state'; 'the state-centric tradition'; and state transformation.

${ }^{9}$ Arguing for a shift from the Keynesian Welfare National State to the Schumpeterian workfare post-national regime, Jessop (2004: 11) describes the hollowing out of state as the re-scaling of the nation-state's powers upwards, downwards or sideways; a shift from state-based government to network-based governance; or incremental changes in secondary aspects of the nation-state that leave its core intact.
} 
explanatory independent variable among others, the literature on Europeanization treats the EU's impact on national arenas as the main explanatory variable.

This article similarly maintains the idea that although new regionalist literature and Europeanization have similarities in identifying variables at the national and regional level in terms of enabling or inhibiting the activities of SNAs, there is a clear difference in their analytical approach to the research object. While scholars working on European regionalism (mainly from the new regionalist tradition) emphasize the multi-causal character of change and ethno-political activities of SNAs in the international arena, Europeanization mainly focuses on single or sometimes dual dimensions with regard to subnational mobilisation. As a main focus, it is sought here to explore the impact of Europeanization (independent variable) on the mobilisation of SNAs from one of the applicant states (dependent variable). To analyse the extent to which the EU integration process has created necessary opportunities and access points for SNAs to involve in the EU multi-level modality, the next section outlines the historical evolution of EU regional policy and its financial incentives by putting particular emphasis on the partnership principle.

\subsection{Developments Underlying the Revival of Subnational Mobilisation in the EU Arena}

The developments throughout European integration correspondingly have served to enhance the importance of territorial politics within states but have had significantly different effects on the old and new members ${ }^{10}$ (Keating, 2006, p. 145). Since the Treaty of Rome, as Keating (1995, p. 17) observed, European regional policies have developed on three dimensions: 1) the co-ordination of national regional policy measures to ensure their conformity to the subsequent treaties, 2) the development of Community funds for regional development and 3) a slow series of moves towards a positive Community regional policy. The last dimension is inspired by the notion of cohesion policy. However, up until the creation of it, while intergovernmental bargaining over the size and distribution of the fund became crucial, SNAs played no role in Community-level discussions, despite being the main policy implementers (Bache, 1998, pp. 40-47). That is, national governments remained the sole gatekeepers between supranational and subnational actors until the formation of the cohesion policy during the mid-1980s.

The Single European Act (SEA) of 1987 and the Maastricht Treaty of 1993 have triggered the role of local and regional authorities both within national and European policy settings (McMaster, 2006; Ferry, 2007). As Huysseunne and Jans (2008) underline, while regional policy became an EU prerogative with the SEA, the Maastricht treaty reinforced the regional dimension of European integration by introducing the principles of partnership and subsidiarity, providing further increases in structural spending and the creation of a cohesion fund to support the most disadvantaged regions and creating the Committee of Regions (CoR) in 1994. Consequently, all these develop-

\footnotetext{
${ }^{10}$ While the old members refer to the EU-15, the new members simply refer to those states participating in the EU after the fifth enlargement process.
} 


\section{Ali Onur ÖZÇELIK}

ments during the 1990s have underpinned the power shift towards Brussels, making many SNAs reorient their activity towards the EU through different extra-state channels (discussed below).

Among others, the Maastricht Treaty was evaluated as the turning point for SNA involvement because it was a solid recognition of the multi-layered structure of EU governance (Hooghe, 1996). Yet, despite the EU's effort in creating a strong subnational level, the foremost problem was that local and regional administrative units in each member state vary in line with their administrative culture. By the discovery of a territorial dimension ${ }^{11}$ through the 1980s, the EU was able to identify the place where the policy was to be implemented, to propose the level at which the policy was to be implemented and to involve the institutions present in the territory (regional and local governments) in the definition of the policy priorities and objectives (Leonardi, 2005, p. 6). This has been mainly exercised by EU cohesion policy.

\section{EU Funding Mechanisms Under The Cohesion Policy}

Cohesion policy, according to the proponents of the MLG approach, is one of the biggest impetuses behind regional and local participation in European politics. It provides a clear empirical ground for the students of EU studies to examine the impact of the Europeanization of a policy on member (and candidate) states' responses and behaviours. Cohesion policy briefly refers to the set of activities aimed at reducing regional and social disparities in the EU. Historically, it consists of three main financial incentives: the European Agricultural Fund for Guidance, the European Social Fund and the European Regional Development Fund ${ }^{12}$ (Bache, 1998, p. 14). Through the overhaul of structural policy and doubling of financial allocations for the structural funds in 1989, all different financial incentives came together under the heading of cohesion policy. Apart from compensating for the negative impact of the SEA, Bache (1998) highlights that the enlargement of the Community to include Portugal and Spain was an important motivation for introducing structural funds.

The Commission was also aware of the fact that the new member states needed assistance in building institutional capacity to participate in regional policy and offered assistance via preaccession funding (Bailey and De Propis, 2004). In the early years of the eastern enlargement process PHARE was used for funding individual projects and involved direct dealing between the Commission and the applicant central governments (Allen, 2008, p. 21). Because of its excessive bureaucracy and insufficiency in preparing the new members from the fifth enlargement for the structural funds, the PHARE was criticized (ibid). This led the Commission to introduce two new programmes to run alongside PHARE. These programmes are the Instrument for Structural Poli-

\footnotetext{
${ }^{11}$ The EU statistical standard for administrative units (NUTS) developed by Eurostat at the beginning of the 1980s, dividing the European territory into five levels of geographic aggregations: from sections of a country (NUTSI) to villages and towns (NUTS V).

12 In 1993, Financial Instruments for Fisheries Guidance was also added to the cohesion policy structure. For an extensive summary of the evolution of EU regional policy and its funding mechanisms, see Armstrong, 1995; Bache, 1998; Leonardi, 2005; Bailey and De Propis, 2006; and Allen, 2008.
} 
cies for Pre-Accession (ISPA) and Special Accession Programme for Agriculture and Rural Development (SAPARD).

The compliance of the new member states with the cohesion policy acquis effectively measured the ability of these states to engage in the type of multi-level and multi-actor governance that characterizes cohesion policy and the other territorialized policy area (i.e. rural development) within the EU (Leonardi, 2005, p. 141). In all of the new members from the fifth enlargement round, the first planning period of the structural funds (2004-06) began within a framework of centralized and hierarchical governance that gave regions and regional actors a limited role, if one at all (Bruzst, 2008, p. 610). In the period 2004-2006, the EU-funded regional development programmes for the first time started being implemented in 12 regions in Turkey, which were designated by the Preliminary National Development Programme (pNDP 2003). Yet the key partners for the implementation of regional programmes under the Pre-accession Financial Assistance to Turkey were largely coming from the central institutions. This suggests a limited decentralization deriving from the EU structural programmes.

In 2007, a single instrument for Pre-Accession Assistance (IPA) came into effect, which replaced the instruments introduced for the 2000-2006 period. IPA currently covers the candidate states (Croatia, F.Y.R. Macedonia and Turkey) and the potential candidate states (Albania, Bosnia and Herzegovina, Montenegro, and Serbia - including Kosovo). With the introduction of IPA, the operational structures have been mostly centralized and thus the EU has gone through a more centralized fund management, undermining any genuine shifts towards the multi-level modality in applicant states. Apart from the Sectoral Monitoring Committee, there is no other institutional channel for those SNAs to participate in the implementation of regional programmes or to establish direct relations with the supranational institutions.

Since the management of structural funds or pre-accession aids, as a main incentive for change in regional policy in member (and candidate) states, some principles have included an 'integrated approach' (using social, regional and agricultural mechanisms in a coherent way), 'concentration' (on target zones), 'additionality' (EU funding was to supplement as opposed to replace national development aid), 'programming' (pluriannual programmes instead of one-off projects) and 'partnership' (Bauer and Börzel, 2010, p. 255). In order to receive EU's pre-accession funds, it is required from applicant states to meet these criteria for implementation.

Among others, the partnership principle provides the Commission with a powerful tool to initiate bilateral relations between the national governments and their regions at the domestic level. This makes the management of structural policy a process of multi-level cooperative policymaking (Hooghe, 1996; Bache, 1998). Bauer and Börzel (2010, p. 255) argue that it promised nothing more than the transformation of vertical relationships via functional policymaking. However, in the light of the EU's requirements, most specifically for the management of structural funds, Brusis (2002, p. 553) points out that EU conditionality played a significant role in the very emergence of regions as a functional unit of territorial governance within applicant states- in some instances acting as a 


\section{Ali Onur ÖZÇELiK}

catalyst of the domestic reform process. It is indeed the case for Turkey because the EU was the main catalyst behind the adoption of NUTS classification and to a certain extent the establishment of RDAs in Turkey. Consequently, from the very narrow perspective of cost-benefit calculations, the financial incentives seemed to be the strongest driver for regional institutional change as well as growing awareness and organizational change in SNAs in Turkey for the sake of benefitting from these funds. However, Bachtler and McMaster (2008) conclude that there is no guarantee that the Structural Funds (particularly the principles of subsidiarity and partnership) will necessarily promote regionalisation and the role of regional authorities in Central and Eastern Europe, at least in the short to medium terms.

\subsection{The Principle of Partnership}

Although the principles of subsidiarity and partnership are evaluated as a key test of Europeanization and in MLG theses in many relevant studies (Bache, 2008; Börzel, 2002), the central focus throughout this paper is on the partnership principle. As remarked by Thielemann (2000), partnership can have strong mobilisation and legitimization effects on member states. He considers that partnership can empower SNAs, but with a caveat that at the same time partnerships have faced strong resistance, even within a federal system like Germany. One may therefore need to elucidate the concept of partnership and its relevant effect on the mobilisation of SNAs across the EU arena.

Retrospectively, the involvement of SNAs in the EU regional policy process has been increased through the adoption of the partnership principle. In the framework regulations from $1988^{13}$, partnership implied only vertical interaction by neglecting the horizontal dimensions and thus it came closer to multi-level government rather than multi-level governance (Sobzcak, 2007). The 1993 and 1999 revisions of European structural and cohesion policy subsequently extended partnership to the social partners. In so doing, the term acquired wider meaning including both private and third-parties, strengthening the horizontal dimensions. Extension towards the horizontal dimensions, however, undermined the privileged role of regional and local authorities (Bauer and Börzel, 2010, p. 256). This created a problem for a country having a statist tradition. Given that public policy is the aggregate of many different interests, values and identities, it is difficult for those countries having a statist tradition to bring economic, social, political and state actors together in a given territorial context as each of them has their own agenda. This situation was in fact remarkable for those states coming from the Communist regime as they had weak and immature local and regional administrative traditions.

During the CEECs' enlargement process, as Bache (2010, p. 65-6) claims, the Commission went back to its earlier partnership requirements which underline the cooperation between tiers of government instead of worrying about horizontal relations among economic, political and social

\footnotetext{
13 'A close consultation between the Commission, the member states concerned and the competent authorities designated by the latter at national, regional, local or other level, with each party acting as a partner in pursuit of a common goal' (EEC, 2052/88).
} 
partners for the CEECs. For him, the legacy of democratic centralism and the corresponding absence of local and regional self-government have provided important institutional barriers for those states. The Commission also tried to reduce political resistance in those states and to keep the enlargement process on schedule. It may be because with the introduction of the IPA fund system, instead of promoting regionalization of fund management, the EU made the allocation of financial incentives more centralized. The EU was worried about transparency in managing the structural funds through regional partners owing to the lack of their institutional and administrative capacity. Consequently, the Commission after 2000 abandoned its previous emphasis on decentralization and instead encouraged the centralized administration of EU assistance by the CEECs in order to ensure the efficient utilization of allocated funds (Baun and Marek, 2008, p. 7; Bauer and Börzel, 2010, p. 256). Even if a certain level of regionalization was promoted in the CEECs from the beginning, the Commission has paradoxically promoted centralization during the accession stages and for the first couple of years after accession (Ertugal, 2007).

The creation of regional arrangements or reinvigoration of the existing SNAs in new member and applicant states does not mean that those SNAs are capable of absorbing a large amount of structural funds. The creation of institutional capability requires time and learning. As Allen (2008, p. 24) reports, there was a question mark about both the capacity and the capability of the new member states to implement structural spending either under a system in which subnational partnerships with the Commission are encouraged or one that places more weight on the activities of the central governments of the member states. In questioning the existence of capacity on subnational levels in new member states, Bailey and De Propis (2004) similarly discuss that they are not in a position to properly participate in multi-level governance partnership schemes partly because the local and regional institutional capacity does not exist, and partly because of the conscious and effective gatekeeping of the new member state national governments. Irrespective of the reasons, what has become clear is that SNAs from new member states from the fifth enlargement round and the incumbent applicant states have a problem with direct access to the EU institutions because of the centralization of EU fund management. This naturally reduces the pulling effect of EU opportunities which had been the case for the old member states, particularly those SNAs from the UK (discussed below). In short, the evolution of partnership principles has reduced the possibility of direct relations between SNAs and supranational institutions. Besides, the national channels, as intergovernmentalists argue, have become more useful for the representation of subnational interests in new member and candidate states (see for instance, Moravscik, 1995).

There is also diversity in the implications of the partnership principle within the old member states. Considering the impact of the partnership arrangements on territorial restructuring within eight members, what Hooghe (1996) found was that actors at different levels- national, subnational and supranational- controlled different resources in different member states, influencing their ability to shape policy implementation within the framework set by EU-level arrangements. Hooghe and Marks (2001, p. 78) also emphasize that cohesion policy has produced a highly uneven pattern of subnational mobilisation across the EU arena. Some scholars even went further to con- 


\section{Ali Onur ÖZÇELIK}

sider that the supposed influence of European regions through direct interest representation is a misperception and stress that greater influence can be achieved by regions via (rather than by passing) their member states (Le Galès and Lequesne 1998; Jeffrey 1997a; 2000, pp. 4-6). This situation is more visible in the centralized states such as the UK, Portugal, Greece and many CEECs because of the excessive gatekeeping role of central institutions. In more decentralized member states, SNAs were better at exploiting the opportunities provided by the partnership requirement (Bache and George, 2006, pp. 374-5).

Summing up, a meaningful regionalization is essential for strengthening the existing subnational level and/or creating new subnational actors in order to initiate subnational mobilisation on the EU level (Brusis, 2010, p. 72). However, considering the entire developments and events (not necessarily related to each other) since the mid-1980s that have been discussed so far, SNAs in many member states have enhanced their role in the European policy-making process. These developments not only enhanced the role SNAs play in several EU policies, such as environment, social policy and implementation of community's funds, but also fortified the extra-state channels in which SNAs have established a direct contact with supranational institutions (Hooghe and Marks, 2001, pp. 81-92). The next section turns its attention to the European activities of SNAs by outlining the channels in which they participate in the EU's multi-level polity.

\section{European Activities Of Subnational Administrations}

Throughout the integration process, new opportunities have been created for interest formulations of SNAs in EU politics. In particular, the Single European Act, the Maastricht Treaty and the principle of partnership marked a decisive step in the development of lobbying in Brussels by a number of SNAs. The 1990s therefore witnessed the multiplication of access points for the activities of SNAs in Brussels, ranging from information gathering to influencing the EU policy-making process. This section cannot take stock of the totality of subnational activities in Brussels. Rather it can present some categorizations around common activities, which are extensively studied by some scholars (Marks et al., 2002; Husseyyune and Jans, 2008). For them, SNAs generally involved in influencing EU policy, lobbying, creating networks, gathering information, securing the EU funds and promoting the outward image of the cities or regions in which they are embedded. Although 'the political influence of SNAs' ${ }^{14}$ is still being contested in academe, the presence of SNAs in Brussels justifies the reinforcement of third-level politics in the multi-layered system of European governance.

Scholars generally analyze six channels for SNAs to access European politics except for the national one (Bomberg and Peterson, 1998; Jeffrey, 1997a; 2000; Hooghe and Marks, 2001; Tatham,

\footnotetext{
${ }^{14}$ The general tendency in the literature is that SNAs are usually more powerful during the implementation and monitoring stage, particularly for the community program. They are also not expected to play a role in high politics issues such as migration, security, and the like, while they may have influence on some low politics issues such as environment, health care, and so forth. For the extensive account on the SNAs' activities in Brussels, see Bullmann, 1997; Bomberg and Peterson, 1998; Jeffrey, 1997a; 2000; Hooghe and Marks, 2001; Tatham, 2008.
} 
2008). These 'extra-state' 15 channels encompass the Council of Ministers, the Commission (especially via DG Regio and DG Enlargement), the European Parliament, the Committee of Regions (the CoR), interregional organizations and liaison offices. Without delving into the extent to which these channels are important for the effective engagement of SNAs to the European policy network 16 , this paper tends to classify them as institutional EU channels (the Council of Ministers, the EU Parliament, the EU Commission and the Committee of Regions) and non-institutional EU channels (interregional organizations and liaison offices) (Bomberg and Peterson, 1998).

\subsection{Institutional EU Channels}

\subsubsection{The Council of Ministers}

The Council of Ministers is no longer the sanctuary of a pure intergovernmentalism. This is because under art. 146 (later changed as art.203) of the Maastricht treaty some member states had a chance to send subnational ministers to act as their delegates on the Council of Ministers (Bullmann, 1997, p. 15; Greenwood, 2003). Only constitutionally and institutionally stronger SNAs (e.g. the German and Austria Länder, Belgian regions and Spanish Comunidad Autónomas and the UK devolved administrations) are currently able to access the Council meetings. As for the situation for the new member states, there is no demand from SNAs to attend the Council meetings (Scherpereel, 2007).

\subsubsection{The European Commission}

Given its role and importance in the institutional framework of the EU, the Commission is one of the most targeted places for interest representation. On the one side, all sorts of interest groups raise their priorities; on the other side, the Commission receives expertise and assistance for doing its job. The Commission generally follows an open door policy not only for regional representatives but also for other non-state organizations due to the Treaty of Amsterdam ${ }^{17}$. However, it would be misleading to draw a conclusion that the open door policy of the Commission aims at weakening the member states and empowering regions.

\footnotetext{
${ }^{15}$ Jeffrey (1997a; 2000) mentions about two broad types of access channels: 'intra-state channels', with indirect SNA access to the EU policy process conducted through the institutions of the member state; and 'extra-state channels', with direct SNA access to European institutions.

${ }^{16}$ For instance, in his quantitative driven research, Tatham (2008) analyzes how and under what conditions these six channels can be more efficient for regional interest representation. Scherpereel (2007) also analyzes the effectiveness of this channel for SNAs from the new member states.

${ }^{17}$ The treaty overtly requested that 'the Commission should (...) consult widely before proposing legislation and, wherever appropriate, publish consultation documents' (Treaty of Amsterdam, Article 7, Protocol on the application of the principles of subsidiarity and proportionality, Provisions 9) (Official Journal C 340, 10 November 1997).
} 


\section{Ali Onur ÖZÇELIK}

\subsubsection{The European Parliament}

The European Parliament is also an effective channel for the promotion of subnational interests, especially when MEPs are elected on the basis of regional constituencies as in the case of the UK, France, Belgium, Ireland or Italy (Tatham, 2008). Although it is still ambiguous to what extent MEPs can be a carrier of regional or local authorities' interests to the other institutions of the European Union, they can still be an efficient way for SNAs to promote their particular interests, bypass their member state's auspices and gain direct access to the Commission's hierarchy (ibid).

\subsubsection{The Committee of Regions (the CoR)}

The creation of the CoR in the aftermath of the Maastricht Treaty of 1991 seemed to be a strong justification of the Commission's attitude towards inputs provided by SNAs ${ }^{18}$. This was echoed in the slogan 'Europe of Regions' (Loughlin, 1997). However, the CoR is still a consultative body, predominantly for the regional and local policies ${ }^{19}$. SNAs from the candidate states can also participate in the CoR activities. As a main EU level institution for the representation of territorial interests in Brussels, many local and regional actors actively engage with EU politics through the CoR in an attempt to influence the EU decision-making process.

With regard to SNAs from non-member states, as Schönlau (2010) argues, the CoR has reached beyond the EU borders through the ongoing process of EU enlargement in order to spread democratic 'values' to the accession countries. In 1997, the CoR made its first contact with SNAs in applicant states (Scherpereel, 2007). The enlargement-related activities are generally folded into the CoR's Commission for External Relations (RELEX). Although its approach to SNAs in the applicant states has been inconsistent over time, those states used that chance to deepen their contacts with existing members (ibid). The CoR also organizes and promotes direct contacts between accession states inside and outside the Union, by establishing working groups or Joint Consultative Committee. Consequently, there is a relationship between the CoR and the applicant states but this was not densely institutionalized.

\footnotetext{
${ }^{18}$ The CoR replaced the Consultative Council of Regional and Local Authorities (CCRLA) which had been established in 1988 as part of the new regional policy regime. The members of the CCRLA had been appointed by two European-wide subnational associations: the Assembly of European Regions and the Council for European Municipalities and Regions.

19 The Maastricht Treaty specified that the CoR had the right to be consulted not only in the adoption and implementation of EU regional policies but also in all policy areas that had implications for European economic and social cohesion. See Schönlau (2010) for a practitioner point of view regarding the institutional trajectory of the CoR and its evolving place within the EU policy process.
} 


\subsection{Non-Institutional Channels}

\subsubsection{Interregional Organizations}

A growing number of interregional organization $\mathrm{s}^{20}$ have congregated several SNAs from different member (and candidate) states for the promotion and representation of territorial interests at the EU level, particularly for the last four decades. Hooghe and Marks (2001, p. 89) emphasize three different ways for the creation of interregional organizations: (1) Created by the Commission and are attached to a specific Community program or initiative (e.g. Leader, Rechar, Retex, Reneval and Recite); (2) Self-directed mobilisation among SNAs with common territorial features or policy problems (e.g. Eurocities, EURADA); and (3) Self-organization on the part of relatively successful regions (e.g. the Four Motors of Europe). Irrespective of how interregional organization has been established, they have initiated formal and informal mechanisms of deepening connections between members from old member states and members from new and applicant states (Scherpereel, 2007, p. 30). In this respect, they have established special committees and working groups and have sponsored conferences aiming to increase mutual understanding and networking among western and eastern members.

\subsubsection{Liaison Offices in Brussels}

The maintenance of a permanent base in Brussels can be regarded as the most explicit evidence suggesting the Europeanization of subnational governance (John, 1996; Moore, 2012). After the first regional offices were established in Brussels in 1984, territorial representation and subnational mobilisation in Europe have become a vigorous debate in the literature (Jeffrey 1997a; Bomberg and Peterson, 1998; Marks et al., 1996; 2002). Statistically, while there were 15 offices in 1988, the number of regional offices reached 54 by the end of 1993 (Marks et al., 2002). In April 2007, 165 regions, 17 local or sub-regional authorities and 18 other entities (mainly representations of regional private-sector entities) were accredited by the Brussels capital region (Huysseunne and Jans, 2008). Although having a liaison office in Brussels is the most costly ${ }^{21}$ option for SNAs to engage with EU politics, the number and capacity of offices has still been increasing. While new members have rushed to establish offices in Brussels, old regions are expanding their capacity by recruiting more staff, deploying more resources and moving to larger and better-located premises (Moore, 2008a, p. 517).

Those constitutionally strong and rich regions from EU-15 countries (German Lander, Spanish Autonomous communities, the devolved administrations of the UK and French regions) are much more enthusiastic than other members. Territorial presence in Brussels, conversely, remains ina-

\footnotetext{
${ }^{20}$ For the list of more interregional organizations see Greenwood, 2003; and for in-depth analysis of the creation of interregional associations during the EU integration process see Weyand, 1997.

${ }^{21}$ Huysseunne and Jans (2008) gauge the required budget of having a presence in Brussels. For them, it ranges from 42.000 to 1.987.700 Euros, with an average of 381.705 Euros
} 


\section{Ali Onur ÖZÇELIK}

dequate for Luxembourg and other highly centralized old member states, such as Portugal, Ireland and Greece. Regional and Local authorities of these countries are limited by only a small amount of capital and major cities (Huysseunne and Jans, 2008).

Greenwood (1997, p. 229) remarks that although Greece, Portugal and Ireland (together with Spain) are the greatest recipients of the structural funds, they are the worst represented in Brussels. Marks et al. (1996) demonstrated that regions having representations in Brussels are not those that obtain the most funding from the EU or the poorest, most needy regions. What they found is that subnational mobilisation is positively associated with the degree of overlap between the competencies of a regional government and the EU as well as with the political distinctiveness of a region. In this respect, they concluded that there is no relation between money (gaining structural funds) and the presence of regional offices in Brussels, rather political factors-and less strongly regional factors - are important for the regional offices in Brussels.

As for situations of SNAs from the new members, the influxes of representations have emerged since 2002. Those in Poland, the Czech Republic, Slovakia, Hungary, Latvia and Romania seem more attracted to the idea of a direct representation in Brussels (see Table 1). Of the new member states, the presence of SNAs from Poland is remarkable since 15 Polish regional offices have been operating in Brussels. SNAs especially from the new member states or candidates have usually followed the path drawn by the previous experiences of other regions from the EU 15 (Scherpereel, 2007). One may therefore assume that the fashion of a liaison office will continue when new members, candidates or non-member states establish their own regional offices on the basis of lesson-drawing from the existing regional offices in Brussels (Moore, 2008a). In this respect, the above hypothesis drawn by Marks et al. (1996) cannot fit into the Polish case. This is mainly because not only does the cost-benefit calculation work but also the Polish case justifies the social learning which leads to an institutional isomorphism within the SNAs in the EU (Scherpereel, 2007). It is also worth noting that even if some regional offices from new members have failed or do not exist anymore, recent years have witnessed the consolidation of regional offices from new member states and the establishment of representations from candidate states (Croatia) or from countries involved in the EU neighbourhood policy (Ukraine) (Huysseunne and Jans, 2008). 
Table 4.1 Number of offices in Brussels established by some member states

\begin{tabular}{lrrr}
\hline Countries & $\begin{array}{r}\text { Number of offices } \\
\text { before the accession }\end{array}$ & $\begin{array}{r}\text { Number of additional offices } \\
\text { after the accession }\end{array}$ & Total \\
Bulgaria & 2 & 2 & 4 \\
Czech Republic & 1 & 7 & 8 \\
Cyprus & 1 & 1 & 2 \\
Estonia & 2 & 1 & 3 \\
Hungary & 1 & 3 & 4 \\
Latvia & - & 3 & 3 \\
Lithuania & - & 1 & 1 \\
Malta & 1 & 1 & 2 \\
Poland & 11 & 4 & 15 \\
Romania & 6 & - & 6 \\
Slovakia & 3 & 3 & 6 \\
Slovenia & - & 1 & 1 \\
Croatia & - & - & 2 \\
Bosnia-Herzegovina & - & - & 1 \\
Turkey & - & - & - \\
\hline
\end{tabular}

Source (Regional Office Contact Directory, 2009)

\section{General Considerations on the Extra-State Channels}

Multi-level governance is a system of decision making in which there are multiple access points and multiple opportunities to exercise influence and pressure, and multiple places at which decisions are made (Goldsmith, 2003, pp. 115). In such a system, there is an extensive subnational mobilisation across all available access points. Yet decision making in this model is described by Hooghe (1996) as "pluralist with an elitist bias", suggesting that only actors with valuable resources can participate. Furthermore, SNAs from member (and candidate) states do not benefit equally from these channels due to the differences in institutional arrangements, legal structures, administrative framework and traditions in their domestic settings.

The variation in the level of mobilisation among regions and cities in member states and a substantial divergence in their agendas for the EU politics have in fact become a centre of attention for a number of scholars. Those scholars have listed a multitude of factors which mainly constrain or enable SNAs to pursue their activities on the EU level. The majority of studies have sought to explain the factors that motivate SNAs to establish their liaison offices in Brussels (Marks, et al., 1996; 2002; Jeffrey, 2000; Husseyyune and Jans, 2008; Tatham, 2008; 2010; Moore, 2011). To 


\section{Ali Onur ÖZÇELIK}

analyze what causes this uneven pattern of mobilisation across the European arena and within the member states, various factors constraining or enabling SNAs to pursue their activities on the EU level have been listed. Scholars have generally pinpointed the domestic context as the key source of variation and highlighted the importance of the national and subnational conditions as the main explanatory variable which underpins subnational mobilisation towards the European arena. The domestic - national and subnational-context of a given SNA largely depends on their engagement with the EU institutions. In this respect, those SNAs operating in Brussels cannot benefit from EU opportunities equally.

Blatter et al. (2009, p. 192) concluded that a large budget in combination with strong regional competencies in foreign relations is the main pathway toward a strongly staffed regional office in Brussels in order to influence EU decision-making. However, Bomberg and Peterson (1998, p. 232) argue the strong constitutional and legal position at home can be a critical source for SNAs, but it does not guarantee access or influence in Brussels and Strasbourg. From a slightly different perspective, Tatham (2008) argues that regional authorities trying to promote their interests directly at the EU level hardly undermine the liberal/intergovernmentalist assumptions as interests' representation and influence are different. Accordingly, one may argue that if interest representation and subnational mobilisation are not that influential, they could be background noise in the EU policy arena.

There is also some strong evidence suggesting that the image of regions as a third-level of EU multi-level governance has evaporated. Keating and Jones (1995, p. 10) argue that the scenario of the Europe of regions ignores the very real power of nation-states, the resilience of their political and bureaucratic elites and the powerful private interests which have invested in them. One may therefore argue that the nation-state may not have disappeared and it still holds the role of gatekeeping but it is being transformed, increasingly penetrated by supranational and subnational influences. Many SNAs cannot succeed in playing an important role in the EU decision-making process because they act as if they are extensions of their respective states or background noise in Brussels and in any other relevant venue for representation (Jeffrey, 2000; Tatham, 2008). Moreover, SNAs are largely confined to regional issues and are not able to extend their scope from regional policy issues to other policy sectors (Börzel, 2002).

Another important undermining factor is that the CoR has not been able to play an important role amongst other formal EU institutions throughout its evolution so it became a consultative body with no real decision-making power (Jeffrey, 1997a, p. 207; Bullmann, 1997; Tatham, 2008). This justifies the fact that regions and localities in the EU have many differences in terms of institutional structures, powers, strategies, and aspirations, showing the practical limits of a Europe of regions thesis (Bullmann, 1997; Tatham, 2008). For instance, as Jeffrey noted (1997a), German Länder participate more strongly and through more channels in European decision-making than Irish or even French regions because they can bring in more resources. As a result, a Europe of the regions is just an ill-defined idea for some authors and utopia for some regions which seek nationalist purposes (Greenwood, 2003). Some privileged regions, mainly from the federal states, could 
act as a third level in European policy. Other regions especially from the new member states or candidates could just follow the path drawn by previous experiences of other regions from the EU15.

Hooghe and Marks (2001) accept the need for further concrete empirical studies on how multi-level governance works in practice. For instance, Marks et al. (1996, p. 189) suggest:

'Regional mobilisation does not empower regional governments in general but only a select subset of them. The picture of regional mobilisation we present here is one of wide divergence among regional governments, rather than convergence. There is little evidence of a Europe of the regions here; rather we have seen the emergence of a Europe with the regions, or more accurately, a Europe with some regions'.

Overall, it may be misleading to think of any homogenously constructed 'Europe of the regions' within the near future due to differences in subnational settings in the European member states in terms of structure, powers and resources (Bullmann, 1997, p. 4). Subnational mobilisation and the effective participation of regions in the EU policy network have become various and depend on the idiosyncrasies of national and subnational factors.

\section{Conclusion}

Of perhaps more immediate relevance for the purposes of this article, developments within the EU have been considered as a significant factor stimulating the interests of SNAs to establish direct relations with the EU institutions in Brussels. Recent years have witnessed an increased recognition of the importance of territorial politics in Europe, and also of the complexities of the subject (Keating, 2006: 153). What has commonly been agreed by a number of scholars is that developments throughout the integration process have advanced the changing nature and growing importance of SNAs' activities in Europe over the last four decades. These developments supporting the state of SNAs in the EU member (and candidate) states include: the completion of the internal market; the revised treaties of the Single European Act and Maastricht; the subsequent reforms of cohesion policy and structural funds; the launch of the principles of partnership, additionality and subsidiarity; the creation of the Committee of Regions; and right to attend the Ministry of Council meetings for some privileged regions. These developments have presented new opportunities for SNAs and therefore they are generally deemed as a major driving force behind the promotion of multi-level governance (Hooghe and Keating, 2006).

The article has also explored the argument of whether the financial incentives and the principle of partnership have had a significant impact on the development of multi-level governance in member and applicant states. Despite the stimulation with the partnership principle since 1988, national governments have in fact remained effective gatekeepers and allowed public and private, regional and local interests to participate in the regional policy-making process but not more than that. In this respect, multi-level participation should not be confused with the multi-level governance (Bailey and De Propis, 2004; Bache, 2008; Allen, 2008). As regards the situation for the SNAs from the new member and candidate states, although the Commission has attempted to shift 


\section{Ali Onur ÖZÇELIK}

them towards a system of multi-level governance in relation to structural policy, the Commission (particularly after the IPA regulations) sent mixed signals and national governments quickly learned their gatekeeping role (Bailey and De Propis, 2004).

The form of subnational mobilisation and the channels where SNAs are able to contact the EU institutions and their activities in Brussels have also been outlined. As a result of these developments in the integration process, the multiplication of access points and the ongoing enlargement process, a large number of SNAs both from member and candidate states have sought to engage with the multi-level polity and to affect the EU-decision making process on their behalf. All of the channels illustrated above suggest that engagement with the supranational institutions and networks has gone hand in hand with SNAs' integration with the Europeanization process. Even if some constitutionally and administratively strong SNAs have mobilized across the EU arena through different channels, they are no more effective individually in relation to influencing EU governance than they are collectively within the CoR or other relevant interregional organizations in Brussels.

What has been revealed from the above analysis is that SNAs are not equally mobilized and there is a variation in their engagement with the EU institutions. While some SNAs have used the multiple channels and established large offices in Brussels, others have used comparatively limited channels. The article therefore proposed that subnational mobilisation is uneven across the member and candidate states and their participation in the multi-level system of EU governance. This raises the important question: What may explain the variation in their engagement with the EU institutions? Scholars again largely address the domestic-national and subnational-level as a source of variation.

All things considered, the broader debate regarding the EU's regional policy initiatives and its related fund mechanisms offers both opportunities and challenges. It is not overstatement to suggest that cohesion policy and its main financial instruments (structural funds, IPA for Turkey) provide the most useful and appropriate 'empirical lenses' through which to observe the interplay between Europeanization and subnational mobilisation at the EU level.

\section{Bibliography}

Allen, D. (2008). 'Cohesion Policy Pre-and Post-Enlargement', in M. Baun and D. Marek (eds.) EU Cohesion Policy after Enlargement, Basingstoke: Palgrave MacMillan, pp. 15-33.

Amin, A. (1999). 'An Institutional Perspective on Regional Economic Development', International Journal of Urban and Regional Research, 23 (2), 365-378.

Bache, I. (2008). Europeanization and Multi-Level Governance: Cohesion Policy in the European Union and Britain, Lanham: Rowman and Littlefield Publisher.

Bache, I. (2010). 'Partnership as an EU Policy Instrument: A Political History', West European Politics, 33 (1), 58-74. 
Bache, I. and George, S. (2006). Politics in the European Union, $2^{\text {nd }}$ Edition, Oxford: Oxford University Press.

Bachtler, J. \& McMaster, I. (2008). 'EU Cohesion Policy and the Role of Regions: Investigating the Influence of Structural Funds in the New Member States', Environment and Planning: Government and Policy, 26 (2), 398-427.

Bailey, D. \& De Propris, L. (2002). 'European Structural Funds, Regional Capabilities and Enlargement: Towards Multi-Level Governance?', Journal of European Integration, 24 (4),30324.

Baun, M \& Marek, D. (eds.) (2008). EU Cohesion Policy after Enlargement, Basingstoke: Palgrave MacMillan.

Bauer, M. W., Börzel, T.A. (2010). 'Regions and the European Union', in H.Enderlein, S. Walti and M. Zurn (eds.), Handbook on Multi-Level Governance, Cheltham: Edward Elgar, pp. 253-267.

Blatter, J. Kreutzer, M. and Thiele, J. (2009). 'Preconditions for Foreign Activities of European Regions: Tracing Causal Configurations of Economic, Cultural, and Political Strategies', Publius: the Journal of Federalism, 40 (1), 171-199.

Bomberg, E. \& Peterson, J. (2000). 'Policy Transfer and Europeanization: Passing the Heineken Test', Queen's Papers on Europeanization, No. 2/2000.

Börzel, T. (2002). States and Regions in the European Union: Institutional Adaptation in Germany and Spain, Cambridge: Cambridge University Press.

Brusis, M. (2002). 'Between EU Requirements, Competitive Politics, and National Traditions: Recreating Regions in the Accession Countries of Central and Eastern Europe, Governance, 15 (4), 531-59.

Brusis, M. (2010). 'European Union Incentives and Regional Interest Representation in Central and East European Countries', Acta Politica, 45 (1), 70-89.

Bruzst, L. (2008). Multi-Level Governance-the Eastern Versions: Emerging Patterns of Regional Developmental Governance in the New Member States, Regional and Federal Studies, 18 (5), 607-627.

Bullmann, U. (1997). 'The Politics of the Third Level', in C. Jeffery (ed.), The Regional Dimension of the European Union: Towards Third Level in Europe?, London: Frank Cass.

Bulmer, S., and C. Lequesne. (2005). The EU and its Member States, Oxford: Oxford University Press.

Dobre, A. M. (2007). 'Europeanisation from a Neo-Institutionalist Perspective: Experiencing Territorial Politics in Spain and Romania', Unpublished PhD Thesis, KU Leuven, Belgium. 


\section{Ali Onur ÖZÇELIK}

Ertugal, E. (2007). 'AB Bolgesel Politikalarinin Uye ve Aday Ulkelere Etkileri' (the Impact of EU Regional Policies on the Members and Candidates), $2^{\text {nd }}$ Regional Development and Governance Conference, 25-27 October, 2007, Izmir.

Ferry, M. (2007). 'From Government to Governance: Polish Regional Development Agencies in a Changing Regional Context', East European Politics and Societies, 21 (3), 447-474.

Fitjar, R. D. (2010). The Rise of Regionalism: Causes of Regional Mobilization in Western Europe, London: Routledge.

Goldsmith, M. J. and Page, E. C. (2010). Changing Government Relations in Europe: From Localism to Intergovernmentalism, $2^{\text {nd }}$ Edition, London: Routledge.

Hooghe, L. (1995). 'Subnational Mobilization in the European Union', West European Politics, 18 (3), 175-98.

Hooghe, L. and Marks, G. (2001). Multi-level Governance and European Integration, Lanham: Rowman and Littlefield Publishers.

Huysseune, M., Jans, T. (2008). 'Representations of local and regional governments to the European Union. Final report',

http://blbe.be/files/studies/Study\%20VUB\%20Region\%20offices.pdf, (accessed on 22.11.2011).

Goldsmith, M. J. (2003). 'Variable Geometry, Multi-Level Governance and Subnational Government in the Millenium', in K. Featherstone \& C. Radaelli, C. (eds.), the Politics of Europeanization, Oxford University Press, pp. 112-133.

Greenwood, J. (1997). Representing Interests in the EU, Hampshire: MacMillan Press.

Greenwood, J. (2003). Interest Representation in the European Union, Basingstoke:Palgrave Macmillan.

Jeffrey, C. (1997a). The Regional Dimension of the European Union: Towards a Third Level in Europe?, London: Frank Cass.

Jeffrey, C. (1997b). 'Regional Information Offices in Brussels and Multi-Level Governance in the EU: A UK-German Comparison', in C. Jeffery, The Regional Dimension of the European Union: Towards Third Level in Europe?, London: Frank Cass, pp. 183-203.

Jeffrey, C. (2000). 'Sub-National Mobilization and European Integration: Does it Make Any Difference?', Journal of Common Market Studies, 38 (1), 1-23.

Jessop, B. (2004). 'Hollowing out the Nation State and Multi-level Governance' in Kennett, P. (ed.), A Handbook of Comparative Social Policy, Cheltenham: Edward Elgar, pp. 11-25

John, P. (1996). 'Europeanization in a Centralising State: Multi-level Governance in the UK', Regional and Federal Studies 6(2), 131-144 
Keating, M. (1995). 'Europeanism and Regionalism' in M. Keating and B. Jones (eds.) The European Union and the Regions, Oxford: Oxford University Press, pp. 1-22.

Keating, M. (2006). 'Territorial Politics in Europe', in P.M. Heywood, E.Jones, M. Rhodes and U.Sedelmeier (eds.), Developments in European Politics, Basinstoke: Palgrave Macmillan.

Keating, M., and Jones, B. (eds) (1995). The European Union and the Regions, Oxford: Oxford University Press.

Keating, M. and Hooghe, L. (1996). 'By-Passing the Nation-State? Regions and the EU Policy Process' in J. J. Richardson (ed.) London: Routledge, pp. 216-29.

Keating, M. \& Loughlin, J. (eds.) (1997). The Political Economy of Regionalism, London: Frank Cass.

Keating, M., and Aldecoa, F. (1999). Paradiplomacy in Action: The Foreign Relations of Subnational Governments, London: Frank Cass Publishers.

Kohler-Koch, B. and Eising, R. (eds.) (1999). The Transformation of Governance in the European Union, London: Routledge.

Le Galès, P. and Lequesne, C. (1998). Regions in Europe, London: Routledge.

Leonardi, R. (2005). Cohesion Policy in the European Union: the Building of Europe, Basingstoke: Palgrave Macmillan.

Loughlin, J. (1996). 'Europe of the Regions and the Federalization of Europe', Publius 26 (4), 141162.

Marks, G. (1993). 'Structural Policy and Multi-Level Governance in the EC' in A. W. Cafruny and G.C. Rosenthal (eds.), The State of the European Community: The Maastricht Debate and Beyond, New York: Longman, pp. 391-410.

Marks, G., Hooghe, L., and Blank, K. (1995). 'EU Integration since 1980s; State Centric Versus Multi-Level Governance', paper presented at the American Political Science Association Meeting, Chicago, August 31-September 3, 1995.

Marks, G., Nielsen, F., Ray, L. Salk, J.E. (1996). 'Competencies, Craks, and Conflicts: Regional Mobilization in the European Union', Comparative Political Studies, 29 (2), 164-192.

Marks, G. (1997). 'An Actor-Centred Approach to Multi-Level Governance', in C. Jeffery (ed.) The Regional Dimension of the European Union: Towards a Third Level in Europe?, London: Frank Cass, pp. 20-38.

Mazey, S. and Mitchell, J. (1993). 'Europe of the Regions? Territorial Interests and European Integration: The Scottish Experience', in S. Mazey and J. Richardson, Lobbying in the European Community, Oxford: Oxford University Press. 


\section{Ali Onur ÖZÇELIK}

McMaster, I. (2006). 'Czech Regional Development Agencies in a Shifting Institutional Landscape', Europe-Asia Studies, 58 (3), 347-370.

Moore, C. (2008a). 'A Europe of the Regions vs. the Regions in Europe: Reflections on Regional Engagement in Brussels', Regional and Federal Studies, 18 (5), 517-535.

Moore, C. (2008b). 'Beyond Conditionality? Regions from the New EU Member States and their Activities in Brussels', Comparative European Politics, 6, 212-234.

Moore, C. (2012). Regional Representation in the EU: Between Diplomacy and Interest Mediation Houndmills, Basingstoke: Palgrave Macmillan.

Moravcsik, A. (1995). 'Liberal Intergovernmentalism and Integration: A Rejoinder', Journal of Common Market Studies, 33 (4), 611-28.

Ohmae, K. (1995). the End of the Nation-State: the Rise of Regional Economies, New York: Simon and Schuster Inc.

Rosenau, J. N. and Czempiel, E.O. (1992). Governance without Government: Order and Change in World Politics, Cambridge: Cambridge University Press.

Scherepereel, J.A. (2007). 'Sub-National Authorities in the EU's Post-Socialist States: Joining the Multi-Level Polity?', Journal of European Integration, 29 (1), 23-46.

Schönlau, J. (2010). 'The CoR at 16: Growing up or Still under Age?', Paper presented at UACES Research Conference, Bruges, $5^{\text {th }}-8^{\text {th }}$ September, 2010.

Sharpe, L. J. (1993). The Rise of Meso Level Government in Europe, London: Sage.

Sobczak, A. (2007). 'The Impact of Europeanization on the Mobilization of Local Actors in European Cities: A Comparative Analysis of Krakow and Glasgow', Panel on Urban Governance, EURA Conference, Pisa, 12-14 September 2007.

Sørensen, G. (2006). 'Transformation of the State', in C. Hay, M. Lister and D. Marsh (eds.) the State: Theories and Issues, Basingstoke: Palgrave MacMillan.

Tatham, M. (2008). 'Going Solo: Direct Regional Representation in the European Union', Regional and Federal Studies, 18 (5), 493-515.

Thielmann, E. (2000). 'Europeanization and Institutional Compatibility: Implementing European Regional Policy in Germany', Queen's Papers on Europeanization, No: 4. 